\title{
Leptospira spp. AND Toxoplasma gondii ANTIBODIES IN VAMPIRE BATS (Desmodus rotundus) IN BOTUCATU REGION, SP, BRAZIL
}

\author{
Zetun CB (1), Hoffmann JL (1, 2), Silva RC (1), Souza LC (1), Langoni H (1, 2)
}

(1) Zoonosis Research Center, NUPEZO, Veterinary Medicine and Animal Husbandry School, São Paulo State University, UNESP, Botucatu, São Paulo State, Brazil; (2) Department of Tropical Diseases, Botucatu Medical School, São Paulo State University, UNESP, Botucatu, São Paulo State, Brazil.

ABSTRACT: The destruction of natural ecosystems has caused several problems to humans and other animals; herein we investigate the close relationship among vampire bats, humans and domestic animals. Toxoplasma gondii and Leptospira spp. infections are two worldwide zoonoses that provoke serious damage to animals. To determine the prevalence of bats seropositive for toxoplasmosis and leptospirosis in the Botucatu region, 204 serum samples of vampire bats (Desmodus rotundus) were tested for $T$. gondii antibodies by modified agglutination test (MAT-t) and for Leptospira spp. by microscopic agglutination test (MAT-I). No animal was tested positive for $T$. gondii while leptospiral positivity was $7.8 \%$ for Pyrogenes, Shermani and Javanica serovars, with titers varying from 100 to 1,600. Thus, it was verified that $D$. rotundus does not play a relevant role in toxoplasmosis epidemiology. However, these bats can be important in the maintenance of Leptospira spp. in the environment.

KEY WORDS: vampire bats, zoonosis, serological survey, public health.

CONFLICTS OF INTEREST: There is no conflict.

FINANCIAL SOURCE: FAPESP.

\section{CORRESPONDENCE TO:}

HELIO LANGONI, Departamento de Higiene Veterinária e Saúde Pública, Faculdade de Medicina Veterinária e Zootecnia, UNESP, Distrito de Rubião Jr, s/n, Botucatu, SP, 18618-000, Brasil. Phone: + 5514 38116270. Fax: + 5514 38116075. Email: hlangoni@fmvz.unesp.br. 


\section{INTRODUCTION}

Chiropterans are one of the most distinct mammals that play an important role in nature spreading seeds, pollinating flowers and controlling the insect population (1, 2). D. rotundus individuals are found in colonies of 20 to 100 that may use caves, tree holes, abandoned mines, house basements, drainpipes, etc. as roosts $(3,4)$.

The presence of vampire bats near residences and livestock in the Botucatu municipality, favored by the creation of several embankments during the construction of Castelo Branco highway with many areas of water drainage pipes, has contributed to the dissemination of many infectious diseases, including toxoplasmosis and leptospirosis, thus constituting a great public health problem (5).

Toxoplasmosis is a parasitic zoonosis caused by Toxoplasma gondii protozoan that presents a worldwide distribution. Moreover, a great part of the human and animal populations is infected by $T$. gondii $(6,7)$. Chiropterans may be infected by ingestion of oocysts present in the environment, food or water contaminated by feces of infected felids; by consumption of bradyzoites present in tissue of infected intermediate hosts; and also by the transmission of tachyzoites via the transplacental route.

Leptospiral infection is another global zoonosis caused by a spirochaeta, namely, Leptospira spp. (8). This bacterium colonizes the kidneys of reservoir animals and is eliminated in their urine. Humans and other animals get infected either directly or indirectly, through skin, oral, nasal or conjunctiva mucosae; however, humans represent a dead-end as accidental hosts $(9,10)$. The most common transmission routes are water, soil and food contaminated with urine of infected animals.

Contaminated bats constitute a significant infection source since they can carry leptospires $(11,12)$. Matthias et al. (13) reported that renal infection rates may differ among bat genera, and that parasitic burden was most frequent in the kidneys of Promops, Desmodus and Myotis that tested positive by PCR in the following respective percentages: $100 \%, 50 \%$ and 33\%. These animals excrete the agent in urine, thus contaminating the environment or even their victims (animals or humans), as they have the habit of urinating while feeding, because wounds caused by vampire bats are a gateway for this bacterium. The possibility that $D$. rotundus may feed on blood of a leptospiremic animal and therefore get infected, should also be considered. 
Due to scarce reports on the role of these bats in the epidemiological chain of leptospirosis and toxoplasmosis, we aimed to study the serological profile of both infections among $D$. rotundus, considering their feeding habits and the potential environmental contamination.

A total of 204 vampire bats (D. rotundus) were captured from: Bofete (36 animals), Pardinho (10), São Manuel (45), Pratânia (24), Botucatu (16), Itatinga (28) and Anhembi (45). Capture was carried out at night between 6 and 11 p.m. using meshes set up in front of roosts, inside pipes under highways, under railways, in front of caves and tree holes. The animals were sent to the Zoonosis Diagnosis Laboratory, in the Department of Veterinary Hygiene and Public Health, UNESP, Botucatu, SP, Brazil, where they were anesthetized in large-mouthed flasks with cotton soaked in sulfuric ether. Blood was collected via intracardiac puncture, and was centrifuged at $1600 \times g$ for 10 minutes. The resulting serum was frozen at $-20^{\circ} \mathrm{C}$.

To investigate Leptospira spp. antibodies, the microscopic agglutination test (MAT-I) was performed according to the Ministry of Health guidelines (14). Previously, screening was carried out and positive samples were titred. The following leptospiral serovars were tested: Australis, Bratislava, Autumnalis, Butembo, Castellonis, Bataviae, Canicola, Whitcombi, Cynopteri, Djasiman, Sentot, Gryppotyphosa, Hebdomadis, Copenhageni, Icterohaemorraghiae, Javanica, Panama, Pomona, Pyrogenes, Hardjo Prajitno, Hardjo Miniswajezak, Hardjo C.T.G., Hardjo Bovis, Wolffi, Shermani, Tarassovi, Andamana and Patoc, considering titration the greatest serum dilution able to agglutinate $50 \%$ or more leptospires, compared to the control. Regarding toxosplasmosis, modified agglutination test (MAT-t) was performed according to Desmonts and Remington (15).

All serum samples were negative to toxoplasmosis and $7.84 \%$ reacted to different leptospiral serovars, with titers ranging from 100 to 1600 (Table 1). 
Table 1. MAT-I results of the studied Desmodus rotundus, with respective serovars and reactive titers

\begin{tabular}{|c|c|c|c|}
\hline Origin & N. samples & N. reagents (\%) & Serovars (titers) \\
\hline Anhembi & 45 & $6(13.33)$ & $\begin{array}{c}\text { Pyrogenes (400), Javanica (200) } \\
\text { Pyrogenes (100) } \\
\text { Shermani (200) } \\
\text { Shermani (100) } \\
\text { Pyrogenes (200) } \\
\text { Pyrogenes (100) }\end{array}$ \\
\hline Bofete & 36 & $1(2.78)$ & Pyrogenes (800) \\
\hline Botucatu & 16 & $0(0.00)$ & - \\
\hline Itatinga & 28 & $0(0.00)$ & - \\
\hline Pardinho & 10 & $2(20.00)$ & $\begin{array}{c}\text { Pyrogenes (1600), Javanica (200) } \\
\text { Pyrogenes (400) }\end{array}$ \\
\hline São Manuel & 45 & $5(11.11)$ & $\begin{array}{c}\text { Pyrogenes (800) } \\
\text { Pyrogenes (800), Javanica (400) } \\
\text { Pyrogenes (100) } \\
\text { Pyrogenes (100) } \\
\text { Javanica (800), Pyrogenes (100) }\end{array}$ \\
\hline Pratânia & 24 & $2(8.33)$ & $\begin{array}{l}\text { Pyrogenes (200) } \\
\text { Pyrogenes (400) }\end{array}$ \\
\hline Total & 204 & $16(7.84)$ & - \\
\hline
\end{tabular}

N.: number of animals; MAT-I: microscopic agglutination test for Leptospira spp.

The toxoplasmosis results agree with Smith and Frenkel (16), who while studying the occurrence of antibodies against T. gondii in insectivorous bats, verified also negative results to Sabin-Feldman dye test in one big brown bat (Eptesicus fuscus), one red bat (Lasiurus borealis), and two evening bats (Nycticeius humeralis). These findings indicate that bats may be infected, but with lower probability than other mammals.

The negative results concerning $T$. gondii were probably due to the fact that vampire bats do not usually have any contact with the soil, where infectious oocysts are found. They only ingest their prey blood and have no contact with bradyzoites 
present in cysts. Thus, infection would only be possible by ingesting blood of an animal at an acute stage of the disease with flowing tachyzoites, which rarely occurs because toxoplasmosis is mostly a chronic disease.

In a study conducted by Smythe et al. (17) in Australia, 28\% of the frugivorous or nectarivorous bats belonging to the genus Pteropus exhibited antibodies for Leptospira spp., which represents seven different serovars, with Australis (75\%) being the most common infectious serovar.

The 7.84\% positivity found herein had Pyrogenes (87.5\%) as the most prevalent serovar, followed by Javanica (25\%), and then by Shermani (12.5\%). The great majority of the chiropterans captured were caught in drainpipes and tunnels where a large number of rodents is found, suggesting leptospiral transmission among rodents, bats and humans/domestic and wild animals, mainly livestock, because bats were captured in rural areas only.

Cox et al. (18) studying Australian flying foxes (Pteropus spp.), found in $11 \%$ of kidney samples Leptospira spp., which indicates that flying foxes, known as fruit bats, are carriers of this pathogen. The identification of one in ten animals with leptospiral DNA suggests that leptospires are more prevalent in flying fox populations than would be expected for a species that is not a carrier.

Thus, the results allow us to conclude that $D$. rotundus, and probably all other bat species, do not play a leading role in the maintenance or transmission of $T$. gondii to humans and to other animals. Further studies should be conducted to establish the role of these animals as Leptospira spp. reservoirs.

\section{ACKNOWLEDGEMENTS}

We thank The State of São Paulo Research Foundation (FAPESP) for the scientific initiation scholarship, FAPESP process n. 2005/02682-5.

\section{REFERENCES}

1. Peracchi AL, Lima IP, Reis NR, Nogueira MR, Ortêncio Filho H. Ordem Chiroptera. In: Reis NR, Peracchi AL, Pedro WA, Lima IP, editors. Mamíferos do Brasil. Londrina: Editora da Universidade Estadual de Londrina; 2006. p.153-230.

2. Taddei VA. Morcegos: algumas considerações sistemáticas e biológicas. Bol Tec Cati. 1983;172:1-31. 
3. Nowak RM. Walkers bats of the world. In: Kuns TH, Pierson ED, editors. Baltimore: Johns Hopkins University Press; 1994. 287 p.

4. Bredt A, Araújo FAA, Caetano-Júnior J. Morcegos em áreas urbanas e rurais: manual de manejo e controle. Brasília: Fundação Nacional de Saúde; 1996. 117 p.

5. Souza LC, Langoni H, Silva RC, Lucheis SB. Vigilância epidemiológica da raiva na região de Botucatu-SP: importância dos quirópteros na manutenção do vírus na natureza. Ars Vet. 2005;21(1):62-8.

6. Dubey JP, Lindsay DS, Speer CA. Structures of Toxoplasma gondii tachyzoites, bradyzoites, and sporozoites and biology and development of tissue cysts. Clin Microbiol Rev. 1998;11(2):267-99.

7. Kawazoe U. Toxoplasma gondii. In: Neves DP, Melo AL, Genaro O, Linardi PM. Parasitologia humana. 10 ed. Rio de Janeiro: Atheneu; 2000. p. 147-56.

8. Noguchi $\mathrm{H}$. The survival of Leptospira (Spirochaeta) icterohaemorrhagiae in nature: observations concerning microchemical reactions and intermediary hosts. J Exp Med. 1918;27(5):609-25.

9. Acha PN, Szyfres B. Zoonosis y enfermedades transmisibles comunes al hombre y a los animales: bacteriosis. 3 ed. Washington: Organización Panamericana de la Salud; 2003. 480 p.

10. Horsch F. Leptospirose. In: Beres J, editor. Doenças infecciosas em animais domésticos. São Paulo: Roca; 1999. p. 305-26.

11. Bunnell JE, Hice CL, Watts DM, Montrueil V, Tesh RB, Vinetz JM. Detection of pathogenic Leptospira spp. infections among mammals captured in the Peruvian Amazon basin region. Am J Trop Med Hyg. 2000;63(5-6):255-8.

12. Liceras de Hidalgo J. Leptospirosis in Tingo Maria, departamento de Huánuco, Peru II. Estudio in animales silvestres. Bol Oficina Sanit Panam. 1981;91(1):47-55.

13. Matthias MA, Díaz MM, Campos KJ, Calderon M, Willig MR, Pacheco V, Gotuzzo E, Gilman RH, Vinetz JM. Diversity of bat-associated Leptospira in the Peruvian Amazon inferred by bayesian phylogenetic analysis of $16 \mathrm{~S}$ ribosomal DNA sequences. Am J Trop Med Hyg. 2005;73(5):964-74.

14. Brasil. Ministério da Saúde. Fundação Nacional de Saúde. Centro Nacional de Epidemiologia. Coordenação de Controle de Zoonoses e Animais Peçonhentos, 1995. Manual de Leptospirose. 2 ed. Brasília: Fundação Nacional de Saúde; 1995. $98 \mathrm{p.}$ 
Zetun CB et al. Leptospira spp. And Toxoplasma gondii antibodies in vampire bats (Desmodus rotundus) in Botucatu region, SP, Brazil. J Venom Anim Toxins incl Trop Dis. 2009;15(3):552

15. Desmonts G, Remington JS. Direct agglutination test for diagnosis of Toxoplasma infection: method for increasing sensitivity and specificity. J Clin Microbiol. 1980;11(6):562-8.

16. Smith DD, Frenkel JK. Prevalence of antibodies to Toxoplasma gondii in wild mammals of Missouri and east central Kansas: biologic and ecologic considerations of transmission. J Wildl Dis. 1995;31(1):15-21.

17. Smythe LD, Field HE, Barnett LJ, Smith CS, Dohnt MF, Symonds ML, Moore MR, Rolfe PF. Leptospiral antibodies in flying foxes in Australia. $\mathrm{J}$ Wildl Dis. 2002;38(1):182-6.

18. Cox TE, Smythe LD, Leung LK. Flying foxes as carriers of pathogenic Leptospira species. J Wildl Dis. 2005;41(4):753-7. 